\title{
ECONOMIC EFFICIENCY OF WATER PROTECTION WITHIN ENVIRONMENTALLY FRIENDLY AND INTEGRATED WATER RESOURCES MANAGEMENT
}

\author{
Marko Bajcetic ${ }^{19}$, Zvonko Brnjas ${ }^{20}$, Bozo Draskovic ${ }^{21}$
}

\begin{abstract}
Economic efficiency of water protection means having a program to control and make water resources achieve water and environmental status targets. The goal of this paper is to point to the importance of economic efficiency of water protection which has a direct impact on the results of any environmentally friendly and integrated water resources management and produces effects measurable at the water-user side. In particular, this paper aims at specifying basic economic elements and limitations of water protection present in environmentally friendly and integrated water resources management systems. Achieved status targets of water resources are the basic parameters which contribute to full integrated management of waters in time and space. Economic efficiency is needed for water and environmental status targets to be achieved in a proper manner and with the right economic instruments and measures. The economic instruments and measures depend on economic policies that govern taxes, charges, fees and the like. Economic efficiency is more comprehensive than cost efficiency which, in environmentally friendly water management, pertains to institutional and operating costs of the measures imposed. The basis of economic efficiency is made of relationships between different offers that enable achieving specific environmental and water status of water resources. From an economic standpoint water protection comes down to achieving such status of water that allows efficient use of water in integrated water management and ecology.
\end{abstract}

KEYWORDS: economic efficiency, water protection, ecology, water management, water quality.

JEL: P28, Q25, Q57

UDC: 005:[502.171:546.212

\footnotetext{
${ }^{19}$ Regular member of the International Academy of Management and Technology (INTAMT) Novi Sad, Serbia

${ }^{20}$ Institute of Economic Science-Belgrade, Serbia

${ }^{21}$ Institute of Economic Science-Belgrade, Serbia
} 


\section{Introduction}

The basic dilemma concerning priority setting in making economic decisions about water protection and ecology is which of them will enable establishing an efficient regulatory and/or economic system. There are two basic theoretic approaches in this: the approach of normative economics and that of positive economics. Economists supporting values of the normative economics and those supporting positive economics have different approach to the question as to whether charges and fees should be introduced for water protection as fiscal (fixed) parameters that existed in the past or should there be a tariff (a price) charged for the use of public resources and the use-value of water. The difference in the approach is a result of different understanding of economic functions, elements and processes which are connected to pure public and public resources and values contained in the use-value of water.

\section{A Water Protection System and Ecology in Water Management}

Water is a natural resource, not a commodity, and services are those that enable achieving its quality targets, or its use-value. Thanks to the services provided, polluted water from a deteriorated natural resource is transformed into good natural resource and new economic resource. Water protection not only requires government regulations but clearly defined functions and elements that serve as a basis for establishing administrative and business processes in economic and financial structures and systems. Transforming the usevalue of water from unused natural resource into economic resource occurs because organizations operating in the water sector are oriented towards increasing economic efficiency. Such orientation implies defining administrative activities and the use of buildings, devices and facilities based on normative and technological basis and measures.

The existing technology, the production and the attitude of citizens towards water accelerate water pollution which requires well-designed water and environmental protection. Water protection is possible on condition that discharging or receiving polluted water is subject to prohibition, different conditions or limitations. The primary concern is to choose between different preventive, technological, economic, regulatory or other solutions that would enable achieving good quality of water at the side of natural persons and legal entities that pollute it. The second important condition lies in the treatment before the used water is released into a recipient body of water and water facilities. Third is achieving the quality target by physically, chemically, biologically and ecologically treating the water area and the drainage basin. There is another special option which is to leave the water to clean itself in the watercourse or for the water to be released into a larger watercourse.

Water protection, as a field, can be grouped according to: (a) pressures and impacts of natural factors and human activities concerning water and environmental protection, protected areas and water usage; (b) changes in the nature of movement and fluctuations in water quality; (c) the methods and procedures for achieving the goals of water protection; (d) types and methods for the implementation of service processes; (e) the ways and methods of providing and performing water protection services; (f) the needs and demand of the public and users, and taxpayers - beneficiaries and (g) the applicable laws on water protection.

Water protection system consists of the elements such as various physical, chemical and biological characteristics of water and technological systems and economic factors which define the limits of allowed impact on water systems wherever there is water protection 
management. The water system can be considered an eco-system given that it includes mutually interconnected factors of different intensity, pressure and effects on water and the environment that require ecological balance. Ecological balance implies sustaining natural diversity, supporting biological production, developing methods to eliminate negative pressures and impacts on water, promoting economic efficiency from the demand for water through services provided by the water sector.

Basic elements of any water policy and water management activity fall under the following areas: (1) water protection and ecology, (2) water (power) services and (3) other activities.

\section{Ecological Aspects of Water Protection}

Water protection includes all changes of the condition and status of water, water services and activities of the public, that is, all the types and manners of influence and pressures caused by natural, economic and other factors resulting from human activities on surface water and ground water and includes specific types of revenues, sources of finance and financial means spent on services and investments. This area targets bureaucratic (administrative) coordination to specify and position water protection and environmental protection within water management. The water quality is determined by means of theoretic and practical elements and methods in chemistry, physics and biology. The water quality, for purposes of water and environment protection, is determined depending in the ecological status of water. Ecological status requires determining (Annex V, EU Water Framework Directive) biological, hydro-morphological, chemical and physical characteristics and general and specific elements of pollutants. Annex V of the WFD sets out in detail specific types of elements relevant for ecological and chemical statuses which require establishing a supervisory, operating and scientific monitoring but also additional monitoring. The results of monitoring are used within an integrated water management system to determine the condition and to specify ecological status which may be (1) poor, (2) unsatisfactory, (3) satisfactory, (4) good and (5) excellent. Such ecological status is combined with chemical status which may be good or bad. Reaching a specific ecological status depends on social, political and in particular economic efficiency and ability to create conditions for accountability of legal entities and natural persons that pollute water and benefit from higher and added value.

\section{Water Services}

Water services in the field of water protection include specific public and private (economic/waterpower) services that concern receiving and retaining used water within surface water and ground water, together with collection of waste water and water drainage and operations of waste water treatment facilities. Public services pertain to administrative and regulatory activities related to water protection and environmental protection, while private services are activities aimed at achieving the water quality targets. Waterpower services are series of tasks, works and processes used by a service provider to meet the needs, wants and demand for water expressed by the population, industry, agriculture and other economic and non-economic stakeholders.

The services supplied are accompanied by instruments for chemical, biological, physical and ecological measures which need to be taken in order to make water reach the predetermined level of quality and in particular the desired ecological level and potential. Such measures and 
instruments (Bajčetić, 2012.) represent values applicable to human, financial and material resources. Resources and financial means that need to be spent are determined according to the condition and status of water that needs to be treated. The offered water protection should contain quantitative and value indicators that measure the existing and the required water quality. These indicators are drawn from analyses of the measured water quality; applied measuring techniques and possibilities of purchasing resources in the market (inputs). The supply includes calculations for particular measures; specific costs; specific payers of waterpower services, that is users and taxpayers; reports on the quality and ecological potential of water before and after applying measures; specific types and values of use-value of water; economic and market influence on doing business at the user-side and influence of services on economy and gross domestic product.

\section{Other Aspects}

Other activities concern organized activities of the public which, although without any influence on the condition and status of water, must be accepted by makers of water policies and by the water sector. These activities may be used to influence the water sector through citizens' associations which propose measures of more efficient water protection. Citizens' activities are voluntary and are carried out within special forms of association.

Given the subject of water protection, irreplaceability, importance and characteristics of water needed for systemic actions aimed at increasing rationality and efficiency in water protection, the government has the leading role in this area. It reflects in creating legal framework and conditions that will enable application of economic and financial measures in water protection. The contents, functions and the interdependence of parameters are of particular importance for shaping the legal framework, economic characteristics and types of biological, physical, chemical and ecological elements in the water management system in the field of water and environmental protection.

\section{Economic Elements and Relationships in Water Protection}

From economic point of view water protection and ecology are a subset of economic policies, instruments and measures that enable meeting the required use-value of water and water and environment quality targets and secure conditions for integrated water management. Economic instruments and measures are used to meet the needs, wants and interests of the population, businesses, and are used in the interest of environmental protection and sustainable development.

Water quality management includes legal norms and measures (laws, rules and sanctions), economic measures (taxes, charges, prices, state grants, loans, finances provided from various funds, economic influences on gross domestic product), institutional measures (state measures and measures of territorial and political communities), political and social instruments (public relations and trust), spatial planning (integration of various interests that meet in space), scientific - research approaches (sampling, analysis, scanning and new solutions) and technological measures (efficiency of procedures).

The EU Water Framework Directive (WFD) suggested using the so-called COMMPS procedure to determine a list of priority substances which will be subject to basic, subsequent and additional protection measures. The application of the COMMPS procedure depends on the 
characteristics of water and a database of hazardous and damaging substances. The WFD recommends using other methods and analyzing and updating the COMMPS procedure every four years.

Also, defining and application of limit values of emissions according to BREF - Best Available Technology Documents and BAT - Best Available Technology documents that are needed for the implementation of the Directive on Integrated Pollution Prevention and Control (Dalmacija, 2010), are particularly important questions. The best available techniques use standard methods for testing water and waste water (ISO, APHA, AWWA, WPCF, WEF, ASTM, AOAC), and in terms of problem solving, especially the problem with sludge, water protection directives are directly applied. Chemical, biological, hydromorphological and physical-chemical elements of the quality and status of water are contained in the WFD and other EU water directives.

Because of its natural attributes and use-value of water, and primarily because of services, water is an economic resource that sustains life and all types of economic activities in the country. Direct, indirect and nontangible use-values of water and the value of services are measured by supply, price and demand, that is, by costs and revenues. The possibilities offered by use-values of water are determined based on different factors that influence economic relations of the water sector and its environment. Those factors are as follows: spatial and time dimensions; the existence of object of trade (service); the existence of service providers, and users (polluters); relationship between the government, the taxpayer-user and charges, taxes and prices; the existence of institutions that influence economic relations (various directorates, agencies, funds, PWC, WC, organized users, companies and natural persons); established economic rules for water protection that provide framework for economic processes; defined models for determining the level and types of protected water, especially for the types and scopes of ecological condition and status of water; government's and societal obligations regarding water protection which are embodied in given and implemented supply of service aimed at addressing the problem with pollution and specific economy of water protection and ecology in macroeconomic framework.

Economic characteristics of water protection efficiency are contained in the supply, demand and prices of services and ,prices“ of water protection, that is, in charges and in particular in taxes. In a mixed economy, which is most widespread, when the government rules or the market are isolated they become inefficient as economic coordination mechanisms of water protection.

The water sector directly offers services that secure water quality and include operations of facilities and devices for water treatment and use of chemical, physical, biological and ecological measures. The main purpose of such services is to alter key characteristics of „discharged“" water and to return it into its natural condition without causing damage to the environment, the population, economy or sustainable development.

The offers of the required or specific water quality are based on a database of water and environmental protection management which includes various types of pollution. Quantifying the causes and the bad effects of water pollution and environmental pollution is done through the ratio of the risk of pollution and services offered by the water sector. Concepts taken from the Environmental Management System - EMS and Environmental Management Accounting - EMA (Mijanović, 2008) are used for calculation of such ratio. Both of these concepts are applied by companies and because of the risk component they are included in offers of services. In drawing up an offer, elements, data and information provided by users are taken into account (Mijanović, 2008), and EMA includes (Marković et 
al., 2012): energy and material accounting, financial management connected with environmental protection, estimates of products' life cycle, cost estimates and measures' impact assessment and cost calculation for externalities.

Demand for water protection (Bajčetić,2012) is a request for addressing problems with water pollution based on two groups of measures: market measures and measures stemming from direct application of laws. Demand occurs because of the needs and wants for solutions to raise economic efficiency at the polluters' side and in the water sector by means of operating (basic) measures and incentives. It means being able to charge polluters at a price or charge formed based on actual social costs. By making polluters pay for removal of pollution they are forced to either establish treatment procedures for the expressed demand or to stop polluting water. The other way is for the government to prescribe mandatory standards of water pollution, that is, quality standards for receiving used, waste and polluted water.

An efficient and the simplest solution for addressing the problem of pollution is to impose fees or taxes on water pollution (depending on the discharge into a natural watercourse or an artificial water body), that is a tariff for services provided to polluters proportional to the quantity and types of pollution. If no taxes or charges for pollution are paid producers specify the price that is equal to their private limit costs. The quantity of pollution is proportional to the scope of production of the polluter with fixed limit costs of pollution of each produced unit, which is the reason to introduce taxes or charges by produced unit which equal the limit costs of pollution. Costs may become an incentive for the polluter when socially acceptable level of pollution may be achieved thanks to services used to address the problem of pollution.

The water sector, that is, the government may propose and conclude agreements on the use of transferable permits which determine maximum possible level of water pollution (demand) for legal entities and natural persons (users). In addition to terms and conditions pertinent to the quantity of pollution, such agreements regulate relationships between the water sector and the polluter concerning the location, space and time of water pollution; types of pollutants; rights and financial obligations of the polluter and the water sector; applied criteria from the offered permit and terms and conditions for expiry of the permit. The agreed terms and conditions may include, as special market conditions, the transfer of pollution rights from one party to another, that is, conditions for trading permits.

Figure 1 graphically shows how the water sector determines market relations for specific quantities of pollution for which permits are offered and issued. Permits are offered based on the conditions which are created by previously specified and taken procedures for receiving polluted (used and waste) water and in particular, depending on the possibility for biological, chemical and physical measures to be applied in water treatment (contained in waterpower services). The supply curve (offers) is vertical because it is created by precisely specified conditions that govern the level and quantity of pollutants that can be discharged into a watercourse. The curve that denotes demand for permits is created by the degree and quantity of pollution and the price of services which eliminate the pollution. When the conditions of pollution are taken into account, the price is determined as point $\mathrm{A}$ on the curve of demand for the price $\mathrm{C}$ which determines the quantity and satisfies the demand. When the water sector is not treating water by applying physical, chemical, biological and ecological measures, that is, when is not providing a previously defined water quality, the quantity of possible pollution discharged into water is dropping while the price is rising (point $\mathrm{C}_{1}$ ) and the offer is new and higher (for the quantity in point $\mathrm{Q}_{1}$ ). If physical, chemical, biological and ecological measures are intensified, new conditions will occur and that will represent lower offer for larger quantities of pollution (quantity $\mathrm{Q}_{2}$ ) and at lower price (point $\mathrm{C}_{2}$ ). Lower offer and price occur 
because of the previous high price of pollution for larger quantities of pollution and the change in the price and quantities causes cyclic change in demand, because when the price is rising the quantities of pollution drop and vice versa. Demand is subject to continuous change and quantities of pollution and the price depend on the supply, that is, on the measuring results and analysis of the selected measures.

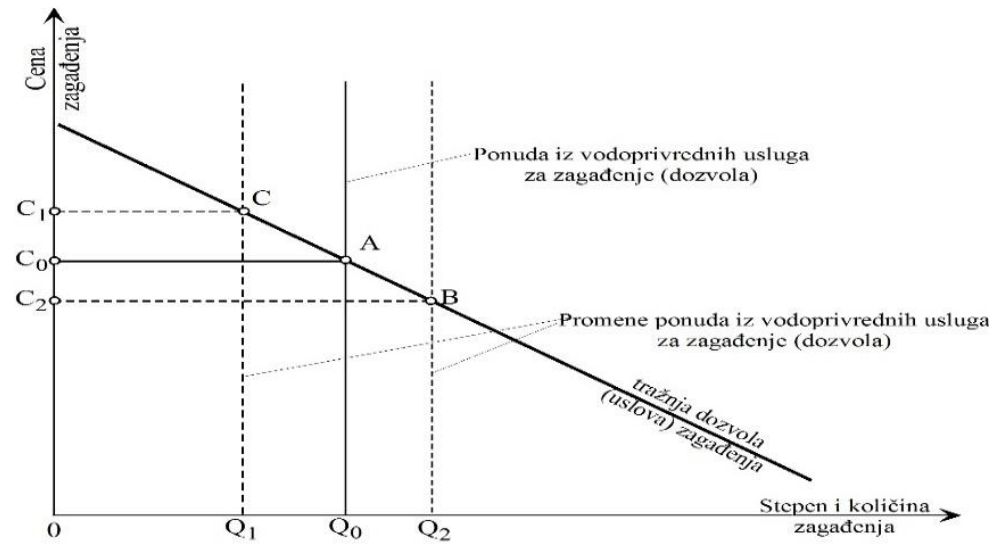

Figure 1: Demand and market relations in water protection from pollution

Willingness to solve pollution problems reflects in the change in demand that has to be lower than the balanced (previous) offer (the line above the demand curve in Figure 2). The decision on the quantity and the degree of pollution is under the influence of market relations and the economic decisions made based on the difference in the relationship between costs and benefits.

\section{Externalities and Economic Limitations in Water Protection}

Sufficient and good water quality changes under the influence of human activities and produces external effects which may be positive or negative, that is useful or harmful. External effects are not accounted for in the price of the services, and they are unidirectional and reciprocal, and the emphasis is put here on natural persons and legal entities that produce bad effects by polluting water and causing damage to water users, the water sector, the environment, and sustainable development. Water is polluted by used and waste water from sewers, industrial facilities, mines, water discharged from agricultural, forest and construction land, from landfills and other areas of human activities.

Externalities (Stiglic,2004) are phenomena caused by the use of water or water pollution, affecting people who do not want to pay for the benefit, or prevention of damage, even though they are the result of human activities and natural processes that take place outside the market exchange. As regards the use of water, externalities occur when a person contributes to the benefits of others, or damage to others by using water (consumption). Externalities are transferred to the third parties who pay for water services, but not necessarily to those who do not pay for water supply and usage.

According to the economics of the public sector the problems with external effects are addressed (Stiglic, 2004) by applying the theory of property rights and the theory of welfare state. The theory of property rights argues that the problem of external effects can be 
addressed by establishing property rights. Water as a natural resource has no owner, and property rights are exercised through the use right. There is another theory known as the Coase Theorem which argues that bargaining of two sides will help address the problem of externalities. The theory of welfare state argues that the problem of externalities is addressed through government's intervention and by internalization of costs of externalities which is done through taxation and subsidies. Taxes are used to prevent damage from pollution and are considered a fine or a price of risk. Such taxes are also known as Pigovian taxes (named after British economist Arthur Pigou) which are introduced to the extent equal to the damage, that is equal to marginal costs of efficient production for each unit of emission or the quantity of quality of water.

Subsidies (Aleksić et al., 2008) are the second most frequently used method for addressing the problem of pollution used in the event of negative externalities and they represent a form of financial assistance provided to polluters by the government.

\section{Conclusion}

Economic efficiency of water protection stemming from a responsible approach to ecology and water resources management is directly proportional to the total and, in particular, to sustainable development as a basic human need for economic growth and equity in the distribution of water resources. This paper clearly pointed and demonstrated dependence of basic economic elements of water protection whose combination enables achieving efficiency. Economic elements contained in the paper, confirm that the efficiency in the protection of water is a special result important for the definition of any ecological system and integrated water management. Because of that, economic efficiency of water protection should be considered a value relevant for achieving the ecological and water status targets of water resources in integrated water management. Economic efficiency of water protection depends on a water management system or on the procedures and processes that enable achieving the status targets of water that satisfy the needs of living beings, requirements of sustainable development and the interests of the population and economy.

The logic of economic efficiency in the protection of water is reflected in a larger value of the ecological status of water and the status of water as a natural resource. The better quality status of water as a resource obtained by water protection the better conditions for obtaining additional value for users of water and achieving greater economic results in the country.

There may be different approaches to determining the type and evaluation of water protection depending on whether economic policies are applied by using the classical, neoclassical, neo-liberal or other economic theories. Economics of water and ecology protection is a particular area within water management and the country's economy. This area requires wider studies to reach economic instruments and measures for the optimization of costs and benefits. Research in economics of water protection is in direct correlation with many economic areas and disciplines.

Any established economic system in the protection of water is expected to be efficient, effective, affordable and equitable, and in particular, not to reduce, but to boost the growth of gross domestic product. The economic system must be established through the interaction of two subsystems which pertain to regulations and market exchangeability between services and water obtained by water protection. 


\section{References}

[1] Aleksić, J., Drašković, B., Mitić, M., Veličković, N. (2008). Ekonomija ekologije i ekonomija ekologije modeli i instrumenti, Ministarstvo zaštite životne sredine, Beograd.

[2] Bajčetić, M. (2012). Integrativnost ekonomije vodnog (javnog) sektora, Prometej, Novi Sad.

[3] Dalmacija, B., Izvori zagađenja vodenog ekosistema neorganskim zagađujućim materijama, Centar izvrsnosti za hemiju okoline i procenu rizika, www.cecra.dh.pmf.uns.rs

[4] Dalmacija, B. (2010). Osnovi upravljanja otpadnim vodama, Prirodno - matematički fakultet, Departman za hemiju i zaštitu životna sredine i Udruženje za unapređenje zaštite životne sredine „Novi Sad,“ Novi Sad.

[5] Marković, Ž. D., Ilić, B. B., Ristić, L. Ž. (2012). Ekološka ekonomija, Etnostil, Beograd.

[6] Mijanović, K. (2008). Okolinski pristup proizvodnim sistemima: čišća proizvodnja, Planjax, Tešanj.

[7] Stiglic, E. Dž.(2004). Ekonomija javnog sektora, Ekonomski fakultet, Beograd.

\section{Article history:}

- $\quad$ Received 22 February 2016

- Accepted 15 May 2016 